\title{
Common problems faced by postgraduate students during their thesis works in Bangladesh
}

\author{
Mohammad A Matin ', Mohammad A W Khan ${ }^{2}$
}

\begin{abstract}
Background: Thesis work is an integral part of postgraduate medical education. It serves as the first stepping stone into scientific writing. But during research work, students and supervisors face various prob-lems. A number of research works has been conducted in different parts of the world on this issue. Some of the problems are candidate related and some of them are supervisor related. In Bangladesh, no re-search work has been done to find out the problems faced by the students and supervisors during thesis work. Once the prob-lems are identified, we can find ways and means to solve those problems as much as possible. Thus the students as the primary group will be benefitted from the results of this study and the supervisors will gain in-sights and will be able to lighten the prob-lems.

Method: A cross sectional descriptive study was conducted in 20 different medical colleges and institutes in Bangladesh. A total of 133 postgraduate students, 46 supervisors participated in the study. Purposive sampling technique was used. Two pretested semi-structured questionnaire were used (one for students and one for supervisors) to collect data and data analysis was done using SPSS version 19.

Results: The problems in general identified were lack of students' knowledge, experience, commitment in thesis works, time constraint, excess workload, lack of fund, inadequate and irregular meeting with supervisors. Institute related problems were inadequate guidance and resources of the institute, absence of research cell and for-mats of thesis writing in the institute and inadequate cooperation from the institute.

Conclusion and recommendation: The pre-sent study revealed that lack of knowledge, lack of experience, lack of fund and lack of regular meetings with supervisor were found the most important general prob-lems. Lack of research project and lack of resource were found the most common problems related to the institute. The rec-ommendations made were- research meth-odology and biostatistics should be incorporated in undergraduate and postgraduate curriculum, regular practical workshops on research methodology and biostatistics for the students and the supervisors, provision of adequate fund for academic thesis works, arrangement of adequate research facilities and resources in all institutes/universities conducting postgraduate courses, introduction of checklist and meeting schedule to be used both by supervisors and students during thesis works.
\end{abstract}

Key Words: Problems faced, postgraduate students, thesis works.

\section{Introduction}

A thesis can be defined as the written prod-uct of a systematic study that results from a period of supervised research at the Uni-versity (BSMMU 2008). The finished prod-uct demonstrates originality, critical and independent thinking, appropriate organization and format, and thorough documentation. It generates scientific mindedness and facilitates the learning of how to identify a research topic and research problem, how to formulate research question(s) and objective(s), how to design and implement a research, how to manage and interpret data and how to report a research.

Thesis work needs to be done in such a precise and systematic

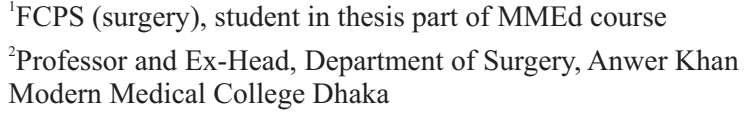

Address of correspondence: Mohammad A Matin

FCPS (surgery), student in thesis part of MMEd course

E-mail: matinabdul53@yahoo.com way so that the students' knowledge, skill, attitudes and values becomes apparent in the thesis work But Many factors affect the thesis works and determine the quality of the thesis writ-ing. These factors may be personal i.e. students' knowledge, experience, commit-ment, socioeconomic condition, communication skill, stress, time management etc. (Bocar 2009), institutional i.e. cooperation, guidance, fund, physical facilities etc.( Safari et al 2015), supervision related i.e. student supervisor relationship, supervisor knowledge and interest, regular contact between supervisor and student, timely feedback etc. (Yousefi et al. 2015), re-search environment related i.e. presence of dedicated faculties and research council/ cell, peer support etc. (Pitchforth et al. 2012).

During the thesis work, the postgraduate students and guides face a variety of difficulties (Duze 2010, Manchishi et al. 2015). Few research works (Lessing \& Schulze 2003, Wang \& Li 2008, Changiz et al. 2003) have been carried out on these issues all over the world. These studies reveal that the problems are mainly concerning the students' clear understanding of the re-search work and the various steps of it.

Bangladesh Journal of Medical Education 2017;8(1):22-27. (C) 2017 Matin et al., publisher and licensee Association for Medical Education. This is an Open Access article which permits unrestricted non-commercial use, provided the original work is properly cited. 
So it is clear that conducting research and thesis writing are quite challenging to the postgraduate students and their supervisors. Quality research has immense beneficial role to meet the society needs, nation needs and global needs. But the number of quality research works and thesis writing carried out by postgraduate students for academic degree is not too many in our country and same picture is prevailing in many other countries. Many factors may affect the postgraduate students' thesis works (Duze 2010, Manchishi et al. 2015, Pitchforth et al. 2012, Bocar 2009, Vos 2013, Myers 1999). This study aims at searching those factors/problems and finding their solution in the context of Bangladesh.

\section{Methods}

This descriptive cross sectional study was conducted in 20 different medical colleges and institutes of Bangladesh during the pe-riod of July 2015 June 2016. Study population were- postgraduate theses students and students who had completed thesis within last 2 years and Supervisors from different discipline. Selection criteria were all available Postgraduate Students in the-sis part who were doing thesis work or had completed the thesis work in different discipline within the last 2 years, all available postgraduate students who were doing dis-sertation/thesis in FCPS $2 \mathrm{nd} / 3 \mathrm{rd}$ part or com-pleted the dissertation/thesis works within the last 2 years, all available supervisors who had supervised at least 2 students and examined at least 5 dissertation/theses. A total of 133 postgraduate students and 46 supervisors were included in the study. Two separate selfadministered semi-structured questionnaire were developed for the students and the supervisors. The instruments were pretested before collect-ing the data.

The researcher introduced himself to the students and supervisors explaining the purpose and the procedure to be followed while filling up the questionnaire. They were assured so that they would not feel any hesitation to answer freely. Question-naire with 5 point Likert scale was used to collect information from the students and the supervisors. Questionnaire was given to the available students just after completion of a class or in their reading room/library/ dormitory/home. For supervisors, the re-searcher met him/her at their office/private chamber to give the questionnaire. Students/supervisors gave the tick mark in the appropriate space on the questionnaire and wrote their comments against the open-ended questions. After completion, the questionnaires were collected by the re-searcher and thanked them for their coop-eration. Questionnaires were edited after collection, coded manually and were un-dergone processed and analyzed by using SPSS version 19 computer software according to the objectives. For each variable frequency distribution and mean score with SD was calculated.

\section{Results}

Results of the self-administered semi-structured questionnaire from the postgraduate students (Table 1) and the supervisors (Table 2) regarding the general problems were as follows-

Table 1 shows that out of total 133 students 27 (20.3\%) students agreed that they had lack of adequate knowledge on assigned task. $55(41.4 \%)$ students agreed that they had lack of adequate experience on as-signed task. 48 (36.1\%) students opined that they did not get enough time to complete the assigned task. 38 (28.6\%) students thought that they were overburdened with the assigned task. 93 (69.9\%) students agreed that they did not have enough fund. 61 $(45.8 \%)$ students agreed that they had inadequate discussion with their supervisor at regular interval.

Table 1: Frequency distribution of opinions on the problems in general during thesis works by postgraduate students ( $\mathrm{n}=133)$.

\begin{tabular}{|c|c|c|c|c|c|c|c|}
\hline \multirow{3}{*}{ Statements } & 1 & 2 & 3 & 4 & 5 & & \multirow[b]{2}{*}{$\begin{array}{l}\text { Mean } \\
\pm \text { SD }\end{array}$} \\
\hline & $\begin{array}{l}\text { Strongly } \\
\text { disagree }\end{array}$ & Disagree & $\begin{array}{c}\text { Neither agree } \\
\text { nor disa- } \\
\text { gree Agree }\end{array}$ & Agree & $\begin{array}{l}\text { Strongly } \\
\text { agree }\end{array}$ & Total & \\
\hline & f $(\%)$ & f $(\%)$ & f $(\%)$ & f $(\%)$ & f $(\%)$ & & \\
\hline $\begin{array}{l}\text { Lack of my adequate knowledge on } \\
\text { assigned task }\end{array}$ & $25(18.8)$ & $64(48.1)$ & $17(12.8)$ & $18(13.5)$ & $9(6.8)$ & 133 & $\begin{array}{l}2.41 \\
1.142\end{array}$ \\
\hline $\begin{array}{l}\text { Lack of my adequate ex-perience on } \\
\text { assigned task }\end{array}$ & $11(8.3)$ & $48(36.1)$ & $19(14.3)$ & $40(30.1)$ & $15(11.3)$ & 133 & $\begin{array}{l}3.00 \\
1.206\end{array}$ \\
\hline $\begin{array}{l}\text { Lack of my commitment/interest to the } \\
\text { assigned task }\end{array}$ & $64(48.1)$ & $44(33.1)$ & $14(10.5)$ & $9(6.8)$ & $2(1.5))$ & 133 & $\begin{array}{l}1.80 \\
.981\end{array}$ \\
\hline $\begin{array}{l}\text { I did not get enough time to complete the } \\
\text { assigned task }\end{array}$ & $31(23.3)$ & $44(33.1)$ & $10(7.5)$ & $37(27.8)$ & $11(8.3)$ & 133 & $\begin{array}{l}2.65 \\
1.327\end{array}$ \\
\hline I was overburdened with the assigned task & $20(15)$ & $41(30.8)$ & $34(25.6)$ & $28(21.1)$ & $10(7.5)$ & 133 & $\begin{array}{l}2.75 \\
1.170\end{array}$ \\
\hline I did not have enough fund & $13(9.8)$ & $16(12)$ & $11(8.3)$ & $45(33.8)$ & $48(36.1)$ & 133 & 3.74 \\
\hline $\begin{array}{l}\text { I had inadequate discus-sion with my } \\
\text { supervisor at regular interval }\end{array}$ & $22(16.5)$ & $39(29.3)$ & $11(8.3)$ & $43(32.3)$ & $18(13.5)$ & 133 & $\begin{array}{l}2.97 \\
1.354\end{array}$ \\
\hline
\end{tabular}

Bangladesh Journal of Medical Education 2017;8(1):22-27. 
Table 2 shows that out of 46 supervisors 33 (71.7\%) agreed that the students had lack of adequate knowledge on the assigned task. $37(80.2 \%)$ supervisors agreed that the students lacked adequate experience on the assigned task. 36
(78.3\%) supervisors agreed that the students did not have enough fund and $38(82.7 \%)$ supervisors opined that the students did not have adequate discussions with the supervisors at regular interval.

Table 2: Distribution of the supervisors' opinions on the problems in general related to the student during thesis works ( $\mathrm{n}=46$ ).

\begin{tabular}{|c|c|c|c|c|c|c|c|}
\hline \multirow{3}{*}{ Statements } & 1 & 2 & 3 & 4 & 5 & & \multirow[b]{2}{*}{$\begin{array}{l}\text { Mean } \\
\pm \text { SD }\end{array}$} \\
\hline & $\begin{array}{l}\text { Strongly } \\
\text { disagree }\end{array}$ & Disagree & $\begin{array}{l}\text { Neither agree } \\
\text { nor disa- } \\
\text { gree Agree }\end{array}$ & Agree & $\begin{array}{l}\text { Strongly } \\
\text { agree }\end{array}$ & Total & \\
\hline & $\mathbf{f}(\%)$ & $\mathbf{f}(\%)$ & f $(\%)$ & $\mathbf{f}(\%)$ & $\mathbf{f}(\%)$ & & \\
\hline $\begin{array}{l}\text { Lack of student's ade-quate knowledge on } \\
\text { as-signed task }\end{array}$ & $1(2.2)$ & $7(15.2)$ & $5(10.9)$ & $27(58.7)$ & $6(13)$ & 46 & $\begin{array}{l}3.65 \\
.971\end{array}$ \\
\hline $\begin{array}{l}\text { Lack of Student's ade-quate experience on } \\
\text { as-signed task }\end{array}$ & $1(2.4)$ & $4(8.7)$ & $4(8.7)$ & $30(65.2)$ & $7(15)$ & 46 & $\begin{array}{l}3.83 \\
877\end{array}$ \\
\hline $\begin{array}{l}\text { Lack of student's com-mitment/interest to } \\
\text { the assigned task }\end{array}$ & $2(4.3)$ & $16(34.8)$ & $13(28.3)$ & $11(23.9)$ & $4(8.7)$ & 46 & $\begin{array}{c}2.98 \\
1.064\end{array}$ \\
\hline $\begin{array}{l}\text { Students did not get enough time to } \\
\text { complete the assigned task }\end{array}$ & $1(2.2)$ & $21(45.7)$ & $9(19.6)$ & $12(26.1)$ & $3(6.5)$ & 46 & $\begin{array}{c}2.89 \\
1.038\end{array}$ \\
\hline $\begin{array}{l}\text { Students are overbur-dened with the } \\
\text { assigned task }\end{array}$ & $5(10.9)$ & $31(67.4)$ & $3(6.5)$ & $7(15.2)$ & - & 46 & $\begin{array}{l}2.26 \\
.855\end{array}$ \\
\hline Students do not have enough fund & $1(2.2)$ & $6(13)$ & $2(4.3)$ & $20(43.5)$ & $16(34.8)$ & 46 & $\begin{array}{c}4.02 \\
1.105\end{array}$ \\
\hline $\begin{array}{l}\text { Inadequate discussion with my supervisor } \\
\text { at regular interval }\end{array}$ & $2(4.3)$ & $4(8.7)$ & $2(4.3)$ & $21(45.7)$ & $17(37)$ & 46 & $\begin{array}{c}4.02 \\
1.085\end{array}$ \\
\hline
\end{tabular}

Results of the self-administered semi-structured questionnaire from the postgraduate students (Table 3 ) and the supervisors (Table 4) regarding the problems related with the institutes were as follows-

Table 3 shows that out of total 133 students 32 (24\%) students opined that they did not get adequate guidance by their institute. $47(35.3 \%)$ students agreed that their institute did not have any research project/cell/council. 72 (54.1) students agreed that their institute did not have adequate resources. $49(30.8 \%)$ students agreed that they did not get adequate formats and examples of thesis writing and only 19 $(14.3 \%)$ students claimed that they did not get cooperation from their institute.

Table 3: Frequency distribution of opinions on the problems related with the institutes by post-graduate students ( $\mathrm{n}=133$ ).

\begin{tabular}{|c|c|c|c|c|c|c|c|}
\hline \multirow{3}{*}{ Statements } & 1 & 2 & 3 & 4 & 5 & & \multirow[b]{2}{*}{$\begin{array}{l}\text { Mean } \\
\pm \text { SD }\end{array}$} \\
\hline & $\begin{array}{l}\text { Strongly } \\
\text { disagree }\end{array}$ & Disagree & $\begin{array}{c}\text { Neither agree } \\
\text { nor disa- } \\
\text { gree Agree }\end{array}$ & Agree & $\begin{array}{l}\text { Strongly } \\
\text { agree }\end{array}$ & Total & \\
\hline & f (\%) & f (\%) & f $(\%)$ & f $(\%)$ & f $(\%)$ & & \\
\hline $\begin{array}{l}\text { I did not get adequate guidance by my } \\
\text { institute }\end{array}$ & $22(16.5)$ & $58(43.6)$ & $21(15.8)$ & $20(15)$ & $12(9)$ & 133 & $\begin{array}{l}2.56 \\
1.196\end{array}$ \\
\hline $\begin{array}{l}\text { My institute did not have any specific } \\
\text { research project/cell/council }\end{array}$ & $12(9)$ & $55(41.4)$ & $19(14.3)$ & $31(23.3)$ & $16(12)$ & 133 & $\begin{array}{c}2.88 \\
1.2193\end{array}$ \\
\hline $\begin{array}{l}\text { I did not have adequate resources (Adequate } \\
\text { dedicated faculties, IT lab/library, fund) }\end{array}$ & $7(5.3)$ & $37(27.8)$ & $17(12.8)$ & $52(39.1)$ & $20(15)$ & 133 & $\begin{array}{l}3.31 \\
1.182\end{array}$ \\
\hline $\begin{array}{l}\text { I did not get adequate formats and exam- } \\
\text { ples of thesis writing }\end{array}$ & $11(8.3)$ & $57(42.9)$ & $16(12)$ & $41(30.8)$ & $8(6)$ & 133 & $\begin{array}{l}2.83 \\
1.13\end{array}$ \\
\hline $\begin{array}{l}\text { I did not get coopera-tion from my own } \\
\text { institute }\end{array}$ & $22(16.5)$ & $76(57.1)$ & $16(12)$ & $11(8.3)$ & $8(6)$ & 133 & $\begin{array}{c}2.30 \\
1.037\end{array}$ \\
\hline
\end{tabular}

Bangladesh Journal of Medical Education 2017;8(1):22-27. 
Table 4 shows that out of total 46 supervisors 28 (60.9\%) agreed that the students did not get adequate guidance by the institute. 37 (80.4\%) supervisors agreed that many institute did not have any specific research project/cell/council. 39
(84.7\%) supervisors agreed that many institutes did not have adequate resources and $33(71.7 \%)$ supervisors agreed that many in-stitutes did not have adequate formats and examples of thesis writing.

Table 4: Distribution of the supervisors' opinions on the problems related with the institute $(n=46)$.

\begin{tabular}{|c|c|c|c|c|c|c|c|}
\hline \multirow{3}{*}{ Statements } & 1 & 2 & 3 & 4 & 5 & & \\
\hline & $\begin{array}{l}\text { Strongly } \\
\text { disagree }\end{array}$ & Disagree & $\begin{array}{c}\text { Neither agree } \\
\text { nor disa- } \\
\text { gree Agree }\end{array}$ & Agree & $\begin{array}{l}\text { Strongly } \\
\text { agree }\end{array}$ & Total & $\begin{array}{l}\text { Mean } \\
\pm \text { SD }\end{array}$ \\
\hline & $f(\%)$ & $f(\%)$ & $f(\%)$ & $f(\%)$ & f $(\%)$ & & \\
\hline $\begin{array}{l}\text { Students do not get adequate guidance by } \\
\text { my institute }\end{array}$ & $1(2.2)$ & $11(23.9)$ & $6(13)$ & $20(43.5)$ & $8(17.4))$ & 46 & $\begin{array}{l}3.50 \\
1.111\end{array}$ \\
\hline $\begin{array}{l}\text { Many institute do not have any specific } \\
\text { research pro-ject/cell/council }\end{array}$ & $1(2.2)$ & $3(6.5)$ & $5(10.9)$ & $26(56.5)$ & $11(23.9)$ & 46 & $\begin{array}{l}3.93 \\
.904\end{array}$ \\
\hline $\begin{array}{l}\text { Many institutes do not have adequate } \\
\text { resources }\end{array}$ & - & $3(6.5)$ & $4(8.7)$ & $29(63)$ & $10(21.7)$ & 46 & $\begin{array}{l}4.00 \\
.760\end{array}$ \\
\hline $\begin{array}{l}\text { Many institutes do not have adequate } \\
\text { formats and exam-ples of thesis writing }\end{array}$ & $1(2.2)$ & $6(13)$ & $6(13)$ & $25(54.3)$ & $8(17.4)$ & 46 & $\begin{array}{l}3.72 \\
.981\end{array}$ \\
\hline $\begin{array}{l}\text { Many students do not get cooperation from } \\
\text { my own institute }\end{array}$ & $1(2.2)$ & $12(26.1)$ & $11(23.9)$ & $19(41.3)$ & $3(6.5)$ & 46 & $\begin{array}{l}3.24 \\
.993\end{array}$ \\
\hline
\end{tabular}

\section{Discussion}

Majority of the supervisors (71.7\%) and few students $(20.3 \%)$ of the present study agreed that the students did not have adequate knowledge on the research works. This finding reflected the difference of per-ception between the supervisors and the students regarding research related knowledge of the students. There might be misconception of the students regarding their own knowledge because the supervisors were the right person to judge the students' knowledge on research methodology. Again this finding was similar to Manchishi et al. (2015) which showed that students did not understand their own topic because they did not read properly. Both the students and supervisors had suggested in the present study that incorporation of research methodology and biostatistics in the undergraduate and postgraduate curriculum would be beneficial.

Safari et al (2015) found in his study that lack of research experience affected the level of interest and participation of students in research activities. Research experience improved the interest and skill of the students in conducting research activities and can be achieved by participation in workshops related to research, SPSS, writ-ing articles etc. This finding is parallel with the opinion of the supervisors in this study $(80.2 \%)$. But less than half of the students (41.4\%) confessed that they had less experience in research works. Probably a number of remaining students $(58.6 \%)$ had incorrect perception about their research experience.

A few of the students (36.1\%) and supervisors (32.1\%) expressed their opinion re-garding time constraint for the completion of thesis work. Again less number of students
(28.6\%) and supervisors (15.2\%) thought that students were overburdened with thesis work. Similar studies done by Bocar (2009), The University of Cincinnati (2001) found that time management and stress management were very important. Failure to keep pace with work plan and work overload, anxiety, isolation, frustration was the problems during thesis works. Though few students and supervisors had complained regarding time constraint and work overloads of the students but the fac-tors need to be addressed to solve the these difficulties for overall improvement of the-sis works of postgraduate students of various disciplines. For each stage of the thesis work, adequate time must be allotted to deal with the unexpected problems (Trimmer and McCrimmon, 1992) because they are often the cause of failure. Present study has suggested for minimum 1 year duration for thesis work and also to provide guideline and format to carry out thesis work.

Majority of the students (69.9\%) and supervisors (78.3\%) admitted that there was lack of fund for thesis work. This finding also support other studies done by Duze (2010), Trigwell \& Dunbar-Goddet (2005) which noted that lack of funding, library facilities, accommodation and personal problems were the obstacles for thesis work. In present study both students and supervisors suggested to provide adequate financial support, institutional support to solve the mentioned problems.

In the present study majority of the super-visors $(82.7 \%)$ and a reasonable number of students $(45.8 \%)$ agreed that the students did not have adequate discussion with the supervisor at regular intervals. There was huge difference of opinion between the supervisors and students. This finding 
showed that many students $(54.2 \%)$ could not realize the importance of regular dis-cussion with the supervisors for thesis work. Drennan and Clarke (2009) found that inadequate discussion at regular inter-val seriously hampered thesis works. To alleviate this problem both the students and the supervisors in the present study suggested that student and supervisor should keep in touch regularly for the adequate progress of the research work and feed-back.

There was difference of perception be-tween the students $(24 \%)$ and the supervisors $(60.9 \%)$ on the issue of inadequate guidance by the institute. It may be due to gap of expectation between the students and the supervisors regarding how much the institute could guide. Majority of the supervisors (80.4\%) and few students (33.5\%) stated that many institutes did not have research project/cell. Researcher thought that the supervisors were in a bet-ter position to give the correct idea about this issue. Both the students and supervisors of the present study also suggested for institutional support to solve the above problem. Safari et al. (2015) revealed in a study that organizational support was very essential factor for effective and quality thesis work. The process of research proto-col provides a guideline along with super-visory and technical support. Pitchforth et al. (2012) also found that the presence of research project in an institute was im-portant for research activities and absence of which could affect timely completion of thesis.

Majority of the supervisors (84.7\%) and a reasonable number of students (54.1\%) agreed about limited resources of their in-stitutes for thesis works. In this issue the students' opinion was vital as they were the customers for the institutional support ser-vice. Similarly there was difference of opinion between students (30.8\%) and supervisors $(71.7 \%)$ regarding the absence of formats and examples of thesis writing in the institute. Similar findings were found in a study conducted by Ramezani et al. (2011) who also demonstrated that pres-ence of research facilities (access to high speed internet and databases proportional to number of students, presence or absence of chemical/equipment in the laboratory) played an important role in conducting re-search activities. In the present study students and supervisors also suggested for ensuring availability of IT lab (internet ac-cessibility), modern library, well-equipped laboratory, dedicated resource personnel and research cell in the institute.

\section{Conclusion and recommendation}

The present study revealed lack of knowledge, lack of experience, lack of fund and lack of regular meetings with supervisor were found the most important general problems. Lack of research project and lack of resource were found the most common problems related to the institute. The recommendations made were- research methodology and biostatistics should be incorporated in undergraduate and post-graduate curriculum, regular practical workshops on research methodology and biostatistics for the students and the super-visors, provision of adequate fund for academic thesis works, arrangement of adequate research facilities and resources in all institutes/universities conducting postgraduate courses, introduction of checklist and meeting schedule to be used both by super-visors and students during thesis works.

\section{References}

1. Bangabandhu Sheikh Mujib Medical University (BSMMU), 2008. How to write a thesis: A Handbook for the Postgraduate Medical Students, BSMMU, Dhaka.

2. Bocar, A.C., 2009. Difficulties Encountered by the Student Researchers and the Effects on Their Research Output.

3. Changiz, T., Adibi, P., Hosseini, M. and Tootoonchi, M., 2003. Viewpoints of Supervisors about the Problems in the Process of Dissertations for General Medicine Program Isfahan University of Medical Sci-ences. Iranian Journal of Medical Education, 3(1), pp.23-33.

4. Drennan, J. and Clarke, M., 2009. Course-work Master's Programmes: The Student's Experience of Research and Research Supervision. Studies in Higher Education, 34(5), pp.483-500.

6. Duze, C.O., 2010. An Analysis of Prob-lems Encountered by Postgraduate Students in Nigerian Universities. J SocSci, 22(2), pp.129-137.

7. Lessing, A.C. and Schulze, S., 2003. Lecturers' Experience of Postgraduate Super-vision in a Distance Education Context. South African Journal of Higher Educa-tion, 17(2), pp.159-168.

8. Manchishi, P.C., Ndhlovu, D. and Mwanza, D.S., 2015. Common Mistakes Com-mitted and Challenges Faced in Research Proposal Writing by University of Zambia Postgraduate Students. International Jour-nal of Humanities Social Sciences and Ed-ucation (IJHSSE), 2(3),pp.126-138.

9. Myers, L.H., 1999. Barriers to Completion of The Doctoral Degree in Educational Ad-ministration. Dissertation Submitted to the Faculty of the Virginia Polytechnic Institute and State University, Blacksburg, Virginia. Pitchforth, J., Beames, S., Thomas, A., Falk, M., Farr, C., Gasson, S., Thamrin, S.A. and Mengersen, K., 2012. Factors Affecting Timely Completion of a PhD: A Complex Systems Approach, Journal of the Scholarship of Teaching and Learning, 12(4), pp.124-135.

10. Ramezani, A.A., Faraji, A., Aliabadi, A., Noormohammadian, A., 2011. The Students' View of Birjand University of Medical Sciences Related to Affecting Factors on Research in Education, Iranian Journal of Education in Medical Sciences.

11. Safari, Y., Navazeshkhah, F., Azizi, M., Ziaei, M., Sharafi, K., 2015. The Effective Factors on the Postgraduate Students' In-terest and Participation in Performing Re-search Activities-Case Study: Kermanshah University of Medical Science. Future of Medical Education Journal, 5(2), pp.3-9 
12. The University of Cincinnati, 2001.Psychological Services Center, Even-ing Clinic, and the Division of Student Af-fairs and Human Resources.

13. Trigwell, K., Dunbar-Goddet, H., 2005. The Research Experience of Postgraduate Research Students at the University of Ox-ford: Institute for the Advancement of Uni-versity Learning, University of Oxford, pp 3- 6.

14. Trimmer, J. F. and McCrimmon, J.M., 1992.Writing with a Purpose. Ball State University, Houghton Mifflin Company.

16. Wang, T., \& Li, L.Y., 2008. Understanding International
Postgraduate Research Students' Challenges and Pedagogical Needs in Thesis Writing. International Journal of Pedagogies and Learning, 4(3), pp.88-96.

17. Yousefi, A., Bazrafkan, L. and Yamani, N., 2015. A Qualitative Inquiry into the Challenges and Complexities of Research Supervision: Viewpoints of Postgraduate Students and Faculty Members. Journal of Ad-vances in Medical Education \& Profession-alism, 3(3), pp.91.

18. Vos, L., 2013. Dissertation Study at the Postgraduate Level: A review of the literature, The Higher Education Academy 